\title{
Representation of History in Chimamanda Ngozi Adichie's Half of a Yellow Sun (2006)
}

\section{Morve Roshan K.}

$\mathrm{Ph} . \mathrm{D}$. Research Scholar, Center for Comparative Literature and Translation Studies, School of Language, Literature and Culture Studies, Central University of Gujarat, India

Volume 2, Number 1/2015

DOI prefix: 10.18034/ajhal

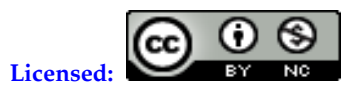

Source of Support: Nil

Conflict of Interest: None Declared

Email for correspondence: morve_roshan@rediffmail.com

\section{ABSTRACT}

This study deals with the conflict of Nigerian Biafran War 6 July, 1960-15 January, 1967 as represented in Chimamanda Ngozi Adichie's novel Half of a Yellow Sun (2006). The study attempts to address the following four questions: first, what are the causes-effects of Biafran/Civil war? Second, why Nigerians have been suffering during the wartime? Third, how does the representation of Nigerian history enable understanding of the post-colonial issues? And final, what is the role of conflict in Nigerian history? In order to understand this conflict, the study addresses the detailed analysis of war conflict, ethnic conflict, class conflict, military conflict and eco-political conflict. The post-colonial approach becomes one of the ways of engaging the theoretical understanding of the novel Half of a Yellow Sun. In sum up, the novel is located with the issues of marginality, history and conflict, which interrogates through post-colonial theoretical formations and the six-phase structure of war novels.

Key Words: Nigeria; post-colonial; Biafran war; history; representation

\section{INTRODUCTION}

The 'postcolonial' in postcolonial writing thus amplifies the nature of its wider cultural work, how it interrogates the past and present operation of historical forces and dominant ways of reading them that underscore local, national and international identities (Mullaney 7).

History as a tool is used by post-colonial writers to reflect their past experiences. Similarly, Nigerian writer Chimamanda Ngozi Adichie also portrays this past in her literary work. She fictionalizes the history to accommodate the question of conflict and internal strife in Nigeria. The issues of identity woven around the war history that is central to Nigerian Biafran historical living experiences in Adichie's second novel Half of a Yellow Sun (2006). It depicts the early and the late 1960s period. It also represents the class, cultural (HausaIgbo), military, ethnic and war conflict. It establishes a connection between the two communities, two groups and two cultures, which have a discrepancy with each other. In addition, the novel also explores and clarifies the problems of the third world countries and the manner in which historical incidence shapes the ordinary man's life. 
In the book entitled, Post Colonial Literature in Context (2010), Julie Mullaney contends that the notion of post-colonial literature preoccupies with the continuing impact of histories of colonialism and with documenting the varied effects of relations of power structure in the formation of identities. He (2010, p.13) writes, "Just as the spread of European colonialism across the continent was often violent and uneven, so the project come out of decolonization and the after colonial nation building has been erratic and traumatic. After the independence from colonial authority, the trials of African nations since independence are often marked by bloody civil wars, military rule, dictatorship, ethnic conflict and genocide, prolonged by continuing social inequalities are critical to an understanding of the social issues facing Africans now." It makes the sense, how the problems faced by African. It directly effects on the people as seen in their violence disrespect and misbehavior.

\section{Presentation}

The history of Nigeria locates within conflictual war crisis that has seriously hampered. It's peaceful existence. Conflict is primarily of two main kinds: internal and external conflict.

Internal conflict is a struggle, which portrays through the characters as well as external conflict occurs the struggle between the character and outside the forces of the circumstances. It can also be struggle of a community. Adichie focuses more on internal conflict, which addresses questions of ethics or morality; the questions of ethics and morality are seen in the characters of Ugwu, Baby, Odenigbo, Richard, Olanna and Kenaine. All these characters have an internal and external conflict with dissatisfy, uncomfortable and unhappy living.

Kwame Anthony Appiah (1992) writes:

For all the while, in African cultures, there are those who will not see themselves as Other. Despite the overwhelming reality of economic decline; despite unimaginable poverty; despite wars, malnutrition, disease and political instability, African cultural productivity grows space: popular literature, oral narrative, poetry, dance, drama, music and visual art all thrive. The contemporary cultural production of many African societies - and the many traditions whose evidence so vigorously remain - is an antidote to the vision of the postcolonial novelist (Barber 1).

Religion may also have played a role in the increasing hostility (Siollun 84). After the economic decline, cultural changes and colonial dominance yet African culture has an important role in the life of African people. A number of major and minor ethnic groups also has been living here and dominated at each other leading to identity struggle. Consequently, the tension between the two communities has led to violence. Kwame Anthony Appiah believes that these different communities do not see themselves as "other" as they consider themselves part of national identity.

John C. Hawley's article titled "Biafra as Heritage and Symbol: Adichie, Mbachu and Iweala" (2008) demonstrates that the Nigerian writing concerns the Biafran war and the picture of the conflict in Mbachu, Uzodinam Iweala, and Adichie. Novels like Adichie's Purple Hibiscus (2005), Mbachu's War Games (2005) and Uzodinam Iweala's Beast of No Nation(2005) are representative of twenty- first century writers' mode of the fictionalizing history. There are the specifics of the Biafran war, towards the universalizing of what that civil conflict can be made to represent. 'The Nigerian identity Adichie tells an interviewer burdensome, what with the suspicion at airports and being told you can't pay with a credit card for Nigerian - related things. The total lack of dignity we encounter at embassies and things of that sort, but I have never wished that I had a different Identity' 
(Hawley 21). Adichie makes these remarks before HYS has been published but goes on to say something that might indicate why she would write such a book: "I do wish that literature can be strong enough to help. But help in what way? If the literature can affect the way one person thinks, and then perhaps it has helped. [...]. I have always hoped for the opportunity to reach higher with each successive book" (Hawley 21). "In common sense, language identification is constructed on the back of recognition of some common origin or shared characteristics with another person or group or with an ideal and with the natural closure of solidarity and allegiance established on this foundation. In contrast with the 'naturalism' of this definition, the discursive approach sees identification as a construction, a process never completed - always process' (Hall and Gay 20). With the concern about identity, "I" is always problematic and contemporary. The self - other these two binaries create the complicated situation in the community or society. Identity is subjectively always in problematic in the context of politically, culturally or socially. It has been a social deconstructed in the way of racial, ethnical, cultural, etc.

Chimamanda Ngozi Adichie born in 1977 in Nsukka, where her father was Vice Chancellor of the University (Hawley 18). Adichie awarded the winner of the 2007 Orange Broadband Prize for Fiction. She is a third-generation Nigerian writer. Born at the end of the war, after the seven years. Her language is very eased to understand the historical events for the readers. She writes in very simple language; readers can be easily assumed that what was the effect of the war. Adichie is a third generation Nigerian writer, who acknowledges Igbo tradition. The novel included 433 pages, every chapter begin with the name of the characters as Olanna, Richard and Ugwu. Though, Richard is a white man, but he reveals that he is "very interested in Igbo-Ukwu Art." Interestingly, included four parts of the book - first and third sections are "The Early Sixties" and another two part "The Late Sixties". It is very clearly described the historical scene has been set in Nigeria as well as pre and post war period. Ugwu, a young houseboy. He lived in Odenigbo's house, in the 15 years joints refugee camp. He becomes a soldier who fights in Nigeria, who played the main role in this novel. The novel HYS genuinely focuses on the Biafran conflict. It is close to the suffering to write the definitive accounts of the war. To assess the war's impact on Nigerian cultural expression in the twenty - first century. Adichie defines how history gets represented in her work. The idea of past experiences, post-colonial as well as a historical way of looking of the Nigerian world. "If the sun refuses to rise, we will make it rise' - the title of Okeomo's poem' (Adichie 411). 'Mrs. Moukelu paused and fingered the plastic half of a yellow sun around her neck' (Adichie 378). Adichie presents the intention for using the title as it defines the symbolic meaning of the half of a yellow sun. Metaphorically, the half of a yellow sun is a symbol of the rising sun on the Biafran flag. It has a new hope for a bright and glorious future. It also identifies that the Nigeria was one country like sun, but it has parted into two states. This is how Nigeria and Biafra separated like the half sun. The sun is comparable with the country, and half means separation of the people or country. The title of the book is influenced from the Biafran flag (As show in the Flag of Biafra). It is a sign of revolt. A clear description of the flag's colours from the teacher of Olanna Ozobia, a beautiful and well-educated Igbo

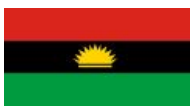
woman. When she does a part in the war effort by teaching a class in a small town to which she and her lover, a nationalist intellectual and his infant love child have been evacuated. 'Red was the blood of the siblings massacred in the North, black was in mourning them, green was for the prosperity Biafra would have. Finally, the half of a yellow sun stood for the glorious future' (Adichie 281). But in the critical view if you see the present condition of Nigeria and Biafra. It is not so glorious and not more in the progressive path. 
Here, Odenigbo's mother calls Olanna "an abnormal woman" and a witch who did not suck her mother's breasts, as if alluding to Olanna's twin birth, which was once, considered an evil phenomenon within the Igbo tradition. She is against the idea of Olanna's marriage to her son (Adichie 96-97). This kind of thinking is indicated of believe of Igbo culture, which is a very valuable thing for Igbo Nigerian.

Hawley argues that because of her "comparative disinterest in the niceties of the war's politics," Adichie is "writing something 'less' than a Biafra novel". I should point out that his assessment is purely quantitative, not qualitative (Hodges 9). I see that Adichie has particularly suitable to carry the structure of Biafran novel. Wendy Griswold identifies as common to many war novels. Basically, it has a six-phase structure:

1. Confidence and high hopes

2. Intimations that all might not go well

3. Ups and Downs of wartime

4. Increasing despair, chaos, death and horror

5. The death of someone who is educated, wise or otherwise highly valued

6. Survival plus disillusionment (Hodges 10).

Adichie's novel encompasses the above six points. Adichie's novel deviate significantly, high hopes for taking education similarly, Ugwu eager to learn an English language very confidently. However, intimations for there is nothing right, the war is a sign of this. In the time of war, ups and downs processed in the life of Ugwu. He joints refugee camp for to protect the Nigerian but takes a different turn and raped. Then there was no destruction of the character but in war conflict and people were dying. There was a disappearance of Kainene. The soldiers have died in the war. The goal of the story Kainene is lost when she went on of attack. 'When the Biafran war erupts; the Igbo loses thousands of lives and their property and bank accounts are confiscated or destroyed. The Ozobias, for instance, lose their family home in the predominantly Yoruba capital city of Lagos and after the fall of Port Harcourt, Kainene's house. During the war, the Igbos are beaten back to interior Igbo towns like Abba, Odenigbo's hometown, where he and Olanna seek refuge from advancing government force' (Mabura 207). The novel successfully makes a war frame with a picturing fictional history of horror, terror and disillusionment. 'Her bank account in Logos was gone... since, she had lost her savings, then she could not possibly lose her sister, to...' (Adichie 432). Olanna has lost her saving bank account.

Here, her disillusionment depicted very fluently as well as confidence and high hopes for loss Kainene. 'I do believe in it. I believe in everything. I believe in anything that will bring my sister home,' she stood up and went to the window. 'Uwam, uwa ozo. When I come back in my next life, Kainene will be my sister' (Adichie 433). This last utterance by Olanna and at the end of the novel Kainene never comes back. It indicated that the hopes disillusionment. The novel tragically ends with the loss of Kainene.

\section{CONCLUSION}

The representation of history of Biafran war gives the sense of existence of war not only in the past but also present. Adichie demonstrates the whole image of historical Nigeria. Adichie also attempts to continue the tradition of the third generation writers in Nigeria. The war conflict which also interrogated violence and how people were exploited leading to the discussion on the majority/minority dynamics along with the fictionalized representation of Nigerian history.

Adichie's writing acknowledges and responds to the conflict in this novel. The historical 
background brings the new lesson to awareness of real history. Adichie attempts at the causes - effects of the war conflict, but also acknowledges the hope for the future and the immediate need for peaceful environment.

\section{REFERENCES}

Achebe, Chinua. Things Fall Apart. 1958. New York: Astor Honor, 1959. Print.

Adichie, Chimamanda Ngozi. Half of a Yellow Sun. London: Harper Perennial, 2006. Print.

Asaah, Augustine H. "Images of Rape in African Fiction: Between the Assumed Fatality of Violence and the Cry for Justice." Annales Aequatori 28 (2007): 333-355. Honore Vinck. Web. 2 November, 2013. 01:49. <http://www.jstor.org/stable/25836912>.

Barber, Karin. Reading in African Popular Culture. London: African Institute School of Oriented and African Studies, 1997. Print.

Hall, Stuart, and P. Du Gay, eds. Questions of Cultural Identity. London: Sage, 1996. Print.

Hawley, John. C. "Biafra as Heritage and Symbol: Adichie, Mbachu, and Iweala." Research in African Literatures 39.2 (Summer, 2008): 15-26. Indiana University Press. Web. 10 August, 2013. 06: 18. <http://www.muse.jhu.edu/journals/ral/summary/v039/39.2hawley.html>.

Hodges, Hugh. "Writing Biafra: Adichie, Emecheta and the Dilemmas of Biafran War Fiction." Postcolonial Text 5.1 (2009): 1-13. Trent University. Web. 9 October, 2013. 01:18. <http://postcolonial.org/index.php/pct/article/viewFile/898/917>.

Mullaney, Julie. Post Colonial Literature in Context. New York: Continuum International Publishing Group, 2010. Print.

Roshan KM. 2014. Contextualizing Power Politics of Tamasha Art and Female Suffering in Dalit Autobiography Asian Journal of Humanity, Art and Literature, 1, 77-83.

This article is is licensed under a Creative Commons AttributionNonCommercial 4.0 International License. Attribution-NonCommercial (CC BYNC) license lets others remix, tweak, and build upon work non-commercially, and although the new works must also acknowledge \& be non-commercial.

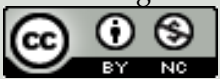

How to Cite: Roshan KM. 2014. Representation of History in Chimamanda Ngozi Adichie's Half of a Yellow Sun (2006) Asian Journal of Humanity, Art and Literature, 2, 23-28. 


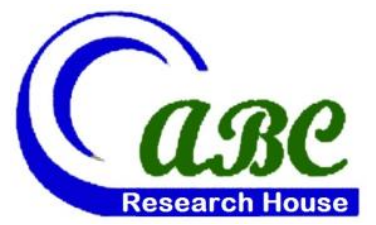

- Off Pantai Dalam, Kuala Lampur, Malaysia

- Road \# 4, Shyamoli, Dhaka-1207, Bangladesh

- 3900 Woodhue Place, Alexandria, VA 22309, USA

www.abcreorg.weebly.com / www.abcjournals.net

Asian Business Consortium (ABC) is a multi-disciplinary research, training, publishing, digital library supporting and service house. Though founded in 2010 as the Business and Computing organization of Asia, it was reconstituted as the ABC in 2011. It has been working for creating and nurturing talents in USA, Malaysia and Bangladesh since its inception. The objectives of consortium are solely centered round the welfare and humane attitude of the founders who enthusiastically took up this noble cause and materialized it with a view to promote research and educational activities for the encouragement of scholars to develop their knowledge, to publish their analysis oriented scientific researches in international Journals, books, the task of organizing workshops, seminars, conferences, training, personality development programs and allied services.

In addition to research activities, $\mathrm{ABC}$ provides a good number of scholarships to the poor and meritorious students at various levels of education throughout the world. It plays an important role in the field of research by funding research projects and publishing the research papers. This consortium will unquestionably become the mouth-piece of the dark horses and unacknowledged scholar whose endowed and commendable contributions shall be provided an outlet keeping in mind the greater good of the larger society of the world.

$\mathrm{ABC}$ runs the following international referred journals for creating a platform to share the thoughts of professionals, scholars and academicians throughout the world.

\section{ABC Publications (ABC Journals)}

- Asian Accounting and Auditing Advancement (4A Journal)

- Asian Business Review (ABR)

- Asian Journal of Applied Sciences and Engineering (AJASE)

- Global Disclosure of Economics and Business (GDEB)

- $\quad$ ABC Journal of Advanced Research (ABC-JAR)

- International Journal of Reciprocal Symmetry and Theoretical Physics (IJRSTP)

- American Journal of Trade and Policy (AJTP)

- Asian Journal of Humanity, Art and Literature (AJHAL)

- Malaysian Journal of Medical and Biological Research (MJMBR)

- Asia Pacific Journal of Energy and Environment (APJEE)

- $\quad$ Engineering International (EI)

- $\quad$ ABC Research Alert (Online)

Each journal home page provides specific information for potential authors and subscribers. Open access policy, the quick review process, rich editorial boards and quality publications have already made ABC Journals unique. ABC Journals are published under the direct supervisions of renowned academicians of the world.

Collaboration in Conference: $\mathrm{ABC}$ considers high-quality conference papers for publication. Please contact us for detailed information.

Collaboration in Publishing: If you like to start writing a book, propose a new journal or advertise in $\mathrm{ABC}$ journals, please feel free to contact us. 